\title{
Efektivitas Ekstrak Daun Pepaya secara Invitro terhadap Colletotrichum gloeosporioides Penyebab Penyakit Antraknosa pada Tanaman Cabai
}

Effectiveness of papaya leaf extract in vitro against Colletotrichum gloeosporioides, the pathogen of the anthracnose disease on red pepper

\author{
Arneti $^{1) *}$, Yenny Liswarni ${ }^{1)}$, Rifa Edriwilya ${ }^{2}$ ) \\ 1)Program Studi Proteksi Tanaman Fakultas Pertanian Universitas Andalas, Padang \\ 2)Program Studi Agroekoteknologi Fakultas Pertanian Universitas Andalas, Padang \\ E-mail: arneti@agr.unand.ac.id \\ Diterima: 18 April 2020 Disetujui: 08 Juni 2020 Dipublikasi: 30 Juni 2020
}

\begin{abstract}
Papaya leaf (Carica papaya Linnaeus) is one of the sources of botanical fungicides that is known to have an ability in inhibiting Colletotrichum gloeosporioides growth. The aim of the study was to determine the effectiveness of papaya leaves extract to suppress of $C$. gloeosporioides growth that caused anthracnose disease of red pepper (Capsicum annuum Linnaeus) in vitro assay. The study was done in a Completely Randomized Design (CRD) with five concentration levels of papaya leaves extract and control $(1 \%, 2 \%, 3 \%, 4 \%, 5 \%$, and control). The parameters were colony growth, colony area, wet weight, dry weight, and conidia number (per $\mathrm{ml}$ of suspension). The data obtained were analyzed by ANOVA and LSD tests at $5 \%$ significance level. The results showed that the application of papaya leaves extract with different concentrations could suppress the growth of $C$. gloeosporioides, the pathogen of anthracnose disease in chili. The higher the concentration of papaya leaves extract given, the higher its effectiveness in suppressing the growth of $C$. gloeosporioides. Application at the $5 \%$ concentration was the most effective inhibiting the conidia formation $(82.5 \%)$, followed by inhibiting the expansion of the colony (64.04\%), reducing wet weight (45.16\%) and dry weight (54.16\%).
\end{abstract}

Keywords: Anthracnose, botanical fungicides, Capsicum annuum, concentration, growth inhibitor

\section{PENDAHULUAN}

Cabai (Capsicum annum Linnaeus) merupakan tanaman semusim yang tergolong dalam family Solanaceae. Cabai termasuk salah satu jenis komoditas holtikultura yang bernilai ekonomis tinggi dan cocok untuk dikembangkan di daerah tropis salah satunya di Indonesia. Berdasarkan data Badan Pusat Statistik (2018), produktivitas tanaman cabai secara nasional cenderung stabil. Data produktivitas dari tahun 2015-2017 berturutturut adalah 8,65 ton/ha, 8,47 ton/ha, dan 8,46 ton/ha, meskipun produktivitas tersebut tergolong rendah dibandingkan dengan produktivitas optimalnya yakni mencapai 20 ton/ha (Nurahmi et al., 2011). $\mathrm{Hal}$ tersebut diduga disebabkan banyak 
faktor, diantaranya serangan hama dan seperti penyakit antraknosa yang disebabkan oleh cendawan Colletotrichum spp.

Duriat et al. (2007) menyatakan bahwa patogen ini dapat menginfeksi buah yang matang maupun buah muda dan menyebabkan buah menjadi busuk. Spesies yang paling banyak menyebabkan penyakit antraknosa di Indonesia adalah C. capsici dan C. gloeosporioides. Spesies C. gloeosporioides dilaporkan paling virulen dibandingkan spesies lainnya. Pada tanaman cabai, C. gloeosporioides mampu menyebabkan kerusakan lebih dari $90 \%$ (Park, 2005).

Salah satu alternatif pengendalian penyakit yang tergolong ramah lingkungan yaitu menggunakan fungisida nabati, diantaranya daun pepaya (Carica papaya Linnaeus). Daun pepaya memiliki kandungan senyawa aktif antara lain tanin, alkaloid, flavonoid, steroid, dan saponin yang bersifat antifungi (Asmaliyah et al., 2010). Suriawiria (2002) melaporkan bahwa daun pepaya mengandung getah berwarna putih yang mengandung enzim pemecah protein atau enzim proteolitik yang disebut papain. Selain itu, Jati (2016) juga melaporkan alkaloid karpain merupakan senyawa penting lainnya yang terdapat dalam ekstrak daun pepaya yang berfungsi sebagai antibakteri. Karpain juga bersifat toksik terhadap mikroba, sehingga efektif dalam membunuh bakteri, jamur, dan virus (Haryani et al., 2012).

Purnomo (2008) menyatakan bahwa pemberian getah pepaya yang berasal dari buah pepaya betina IPB-10 dengan konsentrasi $1 \%$ mampu menurunkan tingkat serangan jamur Colletotrichum sp. penyebab penyakit antraknosa pada buah cabai dengan daya hambat sebesar $28,18 \%$ secara invitro. Belum ada informasi terkait kemampuan ekstrak rebusan daun pepaya dalam menekan penyakit (Siregar dan Emmy, 2005), pertumbuhan jamur $C$. gloeosporioides. Penelitian ini bertujuan untuk mendapatkan konsentrasi ekstrak rebusan daun pepaya yang efektif dalam menekan pertumbuhan $C$. gloeosporioides penyebab penyakit antraknosa pada tanaman cabai secara invitro.

\section{METODOLOGI}

Penelitian ini dilaksanakan di Laboratorium Fitopatologi, Jurusan Hama dan Penyakit Tumbuhan Fakultas Pertanian Universitas Andalas Padang dari bulan Juli sampai September 2019.

\section{Metode}

Penelitian ini disusun dalam Rancangan Acak Lengkap (RAL) dengan 6 perlakuan. Masing-masing perlakuan diulang sebanyak 4 kali. Perlakuan terdiri dari lima konsentrasi ekstrak rebusan daun pepaya yang berbeda dan kontrol (1\%, 2\%, 3\%, 4\%, 5\%, dan kontrol).

\section{Isolasi dan identifikasi jamur $\boldsymbol{C}$. gloeosporioides}

Buah cabai yang terserang antraknosa diambil dari daerah Belimbing, Kecamatan Kuranji Kota Padang, Sumatera Barat. Isolasi jamur dilakukan dengan cara memotong jaringan kulit daging buah (1x1 $\mathrm{cm})$ diantara bagian yang sakit dan sehat, dilanjutkan dengan sterilisasi permukaan menggunakan aquades dan alkohol $70 \%$. Selanjutnya potongan kulit daging buah dibilas dengan aquades steril, dikeringanginkan dan ditempatkan pada cawan petri yang berisi media Potato Dextrosa Agar (PDA). Cawan petri tersebut diinkubasi pada suhu ruang selama 7 hari. Setiap koloni cendawan yang diduga $C$. gloeosporioides dimurnikan kembali pada media PDA. Selanjutnya, dibuat preparat untuk mengamati struktur aservulus dan konidium jamur di bawah mikroskop. Identifikasi C. gloeosporioides dilakukan dengan menggunakan acuan Barnet dan Hunter (1972). 


\section{Pembuatan ekstrak rebusan daun pepaya}

Daun pepaya diambil dari perkebunan pepaya masyarakat di Kecamatan Pauh, Kota Padang. Ekstrak daun pepaya dibuat menggunakan aquades sebagai pelarut. Daun pepaya yang digunakan adalah pepaya betina yang tidak terlalu muda dan tidak terlalu tua, bersih dan tidak terserang penyakit. Sebanyak 5 gram daun pepaya segar dicuci dan dikeringanginkan di tempat yang terhindar dari sinar matahari langsung selama \pm 5 hari. Setelah kering, daun dihaluskan menggunakan blender dan direbus selama 15 menit dalam aquades yang telah dididihkan terlebih dahulu. Air rebusan disaring menggunakan kertas Whatman No. 41. Penyaringan dilakukan sebanyak 2 kali. Kemudian dilakukan pengenceran untuk mendapatkan konsentrasi ekstrak masing-masing sesuai perlakuan.

\section{Uji patogenisitas}

Uji patogenisitas C. gloeosporioides dilakukan pada buah cabai yang sehat menggunakan Postulat Koch. Buah cabai yang diduga terserang C. gloeosporioides diisolasi dan diidentifikasi, kemudian hasil biakan murni diinokulasi kembali pada buah cabai yang sehat. Inokulasi dilakukan dengan cara melukai permukaan buah cabai dengan cara ditusuk menggunakan jarum pentul. Biakan murni jamur yang telah diidentifikasi dipotong menggunakan cork borer (ukuran 0,07 mm) dan ditempelkan pada bagian luka buatan tersebut. Hasil inokulasi harus menimbulkan infeksi dengan gejala yang sama dengan gejala antraknosa yang ditemukan sebelumnya (Gambar 1).

A

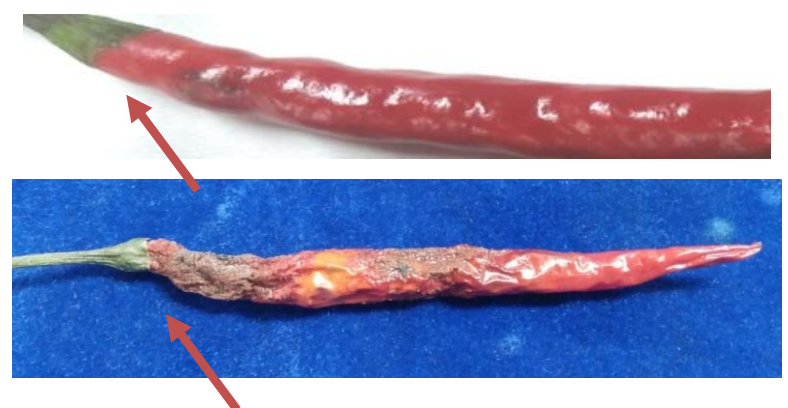

Gambar 1. Hasil uji patogenisitas C. gloeosporioides pada buah cabai yang sehat menggunakan Postulat Koch: A. Gejala awal (3 hsi), dan B. Gejala lanjut (10 hsi).

\section{Uji daya hambat}

Uji daya hambat pertumbuhan $C$. gloeosporioides dilakukan dengan mengukur luas koloni koloni tiap perlakuan pada media PDA. Pengujian dilakukan pada saat miselium berumur 14 hari setelah inokulasi. Sebanyak $1 \mathrm{ml}$ ekstrak daun pepaya tiap perlakuan dicampur dengan $9 \mathrm{ml}$ media PDA cair didalam tabung reaksi dan dihomogenkan, kemudian dituangkan ke dalam cawan petri, dan didiamkan hingga padat. Miselium diambil dengan cara memotong PDA yang ditumbuhi biakan murni $C$. Gloeosporioides menggunakan cork borer berdiameter $7 \mathrm{~mm}$. Selanjutnya miselium ditempatkan pada bagian tengah cawan petri yang berisi campuran PDA dan ekstrak daun pepaya, kemudian diinkubasi dalam inkubator pada suhu kamar dan diamati setiap hari (14 hari).

\section{Pengamatan}

\section{Pertumbuhan koloni $C$. gloeosporioides}

Pengamatan dilakukan ketika cawan petri kontrol telah dipenuhi oleh jamur (14 hari setelah inokulasi) dengan melihat warna koloni, arah pertumbuhan koloni, dan ketebalan miselia untuk masing-masing perlakuan dan membandingkannya dengan kontrol. Data disajikan dalam bentuk tabel. 
Arneti et al. Efektivitas Ekstrak Daun Pepaya

\section{Luas koloni C. gloeosporioides $\left(\mathrm{cm}^{2}\right)$}

Pengukuran luas koloni dilakukan bersamaan dengan pengamatan pertumbuhan koloni yaitu 14 hari setelah inokulasi. Luas koloni diukur menggunakan kertas millimeter ploting dengan cara menggambarkan luas koloni pada plastik kaca. Luas koloni kemudian dihitung menggunakan rumus berikut:

$E=\frac{l k-l p}{l k} \times 100 \%$

Keterangan:

$\mathrm{E}=$ Efektivitas

$\mathrm{Ik}=$ Luas koloni jamur pada kontrol

$I p=$ Luas koloni jamur pada perlakuan

\section{Berat basah C. Gloeosporioides (g)}

Pengukuran berat basah dilakukan dengan penimbangan koloni jamur pada 14 setelah inokulasi. Diperlukan $10 \mathrm{ml} \mathrm{HCl}$ $2.5 \%$ yang telah dipanaskan dengan suhu $50-75^{\circ} \mathrm{C}$ untuk melarutkan agar selama 12 menit. Kertas saring Whatman No. 41 ditimbang terlebih dahulu, kemudian jamur beserta kertas saring ditim-bang lagi menggunakan timbangan analitik. Berat basah koloni jamur dihitung menggunakan rumus:

\section{$\mathbf{B B}=\mathbf{B T}-\mathbf{B k}$}

Keterangan :

$\mathrm{BB}=$ Berat basah $(\mathrm{g})$

$\mathrm{BT}=$ Berat jamur hasil penyaringan

$\mathrm{Bk}=$ Berat kertas saring

\section{Berat kering C. Gloeosporioides (g)}

Pengukuran terhadap berat kering jamur C. gloeosporioides dilakukan setelah penimbangan berat basah jamur. Miselia jamur dibungkus dengan kertas saring Whatman No. 41 lalu dikeringkan dengan oven pada suhu $60^{\circ} \mathrm{C}$ selama 48 jam (sampai berat kering konstan). Selanjutnya, miselia ditimbang menggunakan timbangan analitik. Berat kering koloni jamur dihitung menggunakan rumus:

\section{$\mathrm{BK}=\mathrm{BT} \mathbf{x} \mathbf{B k}$}

Keterangan:

$\mathrm{BB}=$ Berat kering $(\mathrm{g})$
$\mathrm{BT}=$ Berat jamur hasil penyaringan yang telah di oven

$\mathrm{Bk}=$ Berat kertas saring

\section{Jumlah konidia jamur/ml suspensi}

Penghitungan jumlah konidia jamur dilakukan pada 14 hari setelah inokulasi, dengan cara menuangkan sebanyak $10 \mathrm{ml}$ akuades steril ke dalam cawan petri yang berisi biakan jamur. Selanjutnya, konidia dilepas menggunakan kuas sehingga diperoleh suspensi jamur. Pada tahapan selanjutnya, dilakukan pengenceran suspensi konidia sampai $10^{-3}$. Satu tetes suspensi konidia hasil pengenceran diambil menggunakan pipet tetes dan diletakkan diatas Haemocytometer. Penghitungan dilakukan pada 5 kotak besar yang dipilih secara acak (1 kotak besar terdiri dari 16 kotak kecil). Jumlah konidia jamur/ml suspensi dihitung berdasarkan rumus:

\section{$\mathbf{S}=\mathbf{R} \times \mathbf{K} \times \mathbf{F}$}

Keterangan :

$\mathrm{S}=$ Jumlah konidia jamur/ $\mathrm{ml}$ suspensi

$\mathrm{R}=$ Jumlah rata-rata konidia pada 80 kotak kecil

$\mathrm{K}=$ Konstanta koefisien alat $\left(4 \times 10^{6}\right)$

$\mathrm{F}=$ Faktor pengenceran yang dilakukan $\left(10^{-3}\right)$

\section{Efektivitas perlakuan}

Efektivitas ekstrak rebusan daun pepaya dalam menekan luas koloni, berat basah, berat kering dan jumlah konidia $C$. gloeosporioides dihitung menggunakan rumus berikut:

\section{$E=\mathbf{d k}-\mathbf{d p} / \mathbf{d k} \times 100 \%$}

Keterangan:

$\mathrm{E}=$ Efektivitas

$\mathrm{dk}=$ data pada kontrol (\%)

$\mathrm{dp}=$ data pada perlakuan $(\%)$

\section{Analisis data}

Data yang diperoleh dari hasil pengamatan dianalisis mengggunakan sidik ragam dan dilanjutkan dengan uji lanjut Least Significant Difference (LSD) pada taraf nyata $5 \%$. 
HASIL

\section{Pertumbuhan koloni C. Gloeosporioides}

Secara makroskopis, koloni $C$. Gloeosporioides berwarna putih keabuabuan dengan bagian bawah berwarna kecoklatan. Bentuk koloni seperti kapas dan arah penyebaran melingkar secara konsentris. Secara mikroskopis, bentuknya koloni tidak beraturan dengan hifa bersekat dan konidia berbentuk batang dengan ujung yang membulat (Tabel 1 , Gambar 2).

Tabel 1. Karakteristik makroskopis dan mikroskopis jamur C. gloeosporioides

\begin{tabular}{lll}
\hline Karakteristik & Pengamatan & Hasil pengamatan \\
\hline A. Makroskopis & 1.Warna koloni & $\begin{array}{l}\text { Putih keabu-abuan dengan bagian bawah } \\
\text { berwarna kecoklatan }\end{array}$ \\
& $\begin{array}{l}\text { 2. Bentuk koloni } \\
\text { 3. Penyebaran koloni }\end{array}$ & $\begin{array}{l}\text { Seperti kapas } \\
\text { Melingkar secara konsentris }\end{array}$ \\
& 4. Arah pertumbuhan koloni & Menyebar kesegala arah \\
\hline B. Mikroskopis & 1. Bentuk, warna aservulus & Tidak beraturan, tanpa setae, hialin \\
& 2. Hifa & Bersekat \\
& 3. Konidia & Berbentuk batang dengan ujung membulat \\
\hline
\end{tabular}
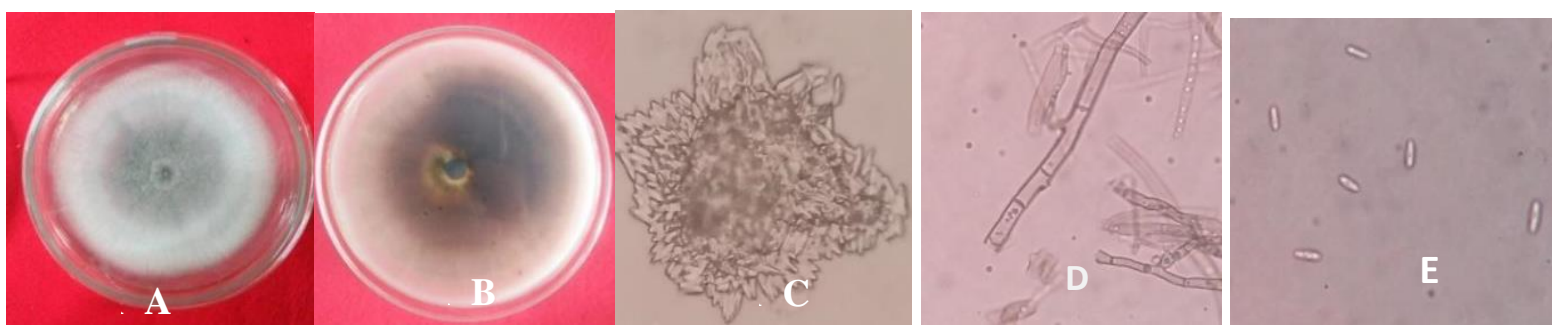

Gambar 2. Bentuk makroskopis dan mikroskopis C. gloeosporioides (14 hsi): (A) Koloni tampak atas, (B) Koloni tampak bawah, (C) Aservulus (pembesaran 100x), (D) Hifa (perbesaran 400x), (E) Konidia (perbesaran 400x).

Aplikasi ekstrak rebusan daun pepaya mempengaruhi warna koloni, penyebaran koloni, dan ketebalan miselia, tetapi tidak berpengaruh terhadap arah pertumbuhan koloni. Warna koloni tampak atas pada perlakuan berwarna putih, dengan garis melingkar yang dihasilkan oleh koloni tampak bawah terlihat jelas. Miselia C. gloeosporioides dengan perlakuan ekstrak daun pepaya terlihat seperti kapas tipis, semakin ke tengah lingkaran terlihat semakin menebal (Tabel 2, Gambar 3).

Tabel 2. Pertumbuhan koloni jamur C. gloeosporioides (umur $14 \mathrm{hsi}$ ) setelah diaplikasi dengan ekstrak rebusan daun pepaya pada konsentrasi yang berbeda

\begin{tabular}{|c|c|c|}
\hline Pengamatan & Kontrol & Dengan perlakuan \\
\hline Warna koloni & $\begin{array}{l}\text { Bagian atas putih keabu-abuan } \\
\text { dan bagian bawah kecoklatan }\end{array}$ & $\begin{array}{l}\text { Bagian atas putih dan bagian } \\
\text { bawah berwarna kecoklatan }\end{array}$ \\
\hline Penyebaran koloni & $\begin{array}{l}\text { Melingkar dengan garis melingkar } \\
\text { tidak begitu jelas (dilihat dari } \\
\text { koloni tampak bawah). }\end{array}$ & $\begin{array}{l}\text { Melingkar dengan garis } \\
\text { melingkar yang jelas (dilihat } \\
\text { dari koloni tampak bawah) }\end{array}$ \\
\hline $\begin{array}{l}\text { Arah pertumbuhan } \\
\text { koloni }\end{array}$ & Menyebar ke segala arah & Menyebar ke segala arah \\
\hline Ketebalan miselia & Tebal secara menyeluruh & Menebal ke tengah \\
\hline
\end{tabular}




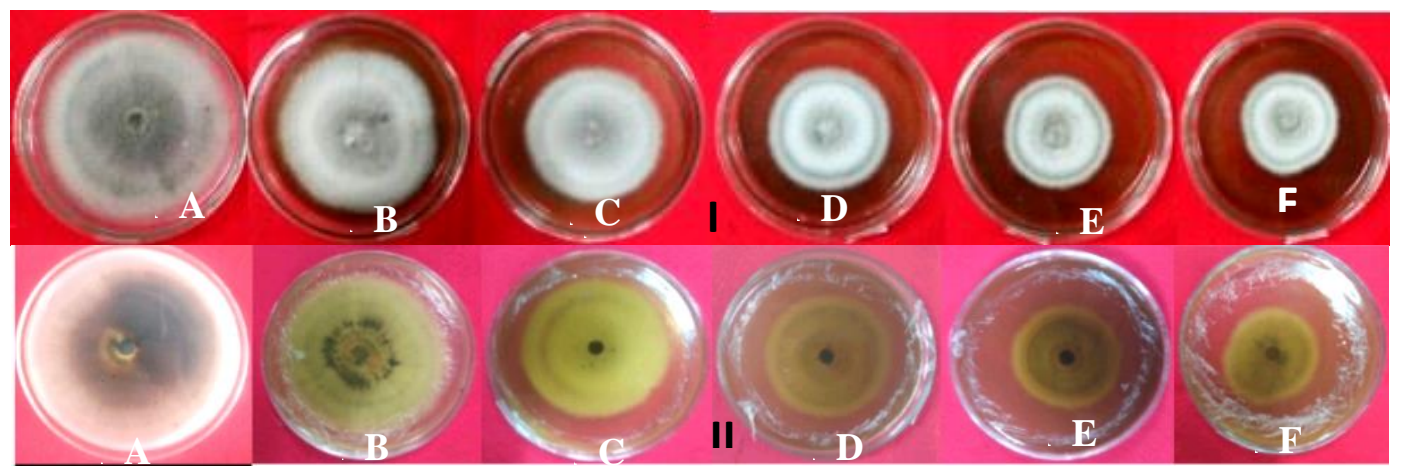

Gambar 3. Bentuk koloni jamur C. gloeosporioides setelah diaplikasi dengan ekstrak rebusan daun pepaya pada hari ke-14 pada beberapa konsentrasi yang berbeda: (I) tampak atas, (II) tampak bawah, (A) Kontrol, (B) Konsentrasi 1\%, (C) Konsentrasi 2\%, (D) Konsentrasi 3\%, (E) Konsentrasi 4\%, (F) Konsentrasi 5\%.

\section{Luas koloni C. gloeosporioides}

Aplikasi ekstrak rebusan daun pepaya dengan konsentrasi berbeda telah menghambat perluasan koloni jamur $C$. gloeosporioides. Semakin tinggi konsentrasi, semakin tinggi pula tekanannya terhadap perluasan koloni jamur. Aplikasi pada konsentrasi $5 \%$ menunjukkan tekanan paling tinggi dengan efektivitas penekanan mencapai $64,04 \%$, tapi tidak berbeda nyata dengan perlakuan $4 \%$ (Tabel 3).

Tabel 3. Luas koloni C. gloeosporioides setelah diaplikasi dengan ekstrak rebusan daun pepaya pada konsentrasi yang berbeda (umur $14 \mathrm{hsi}$ )

\begin{tabular}{lcl}
\hline Konsentrasi & Luas koloni $\left(\mathbf{c m}^{\mathbf{2}}\right)$ & Efektivitas (\%) \\
\hline Kontrol & 55,95 a & - \\
$1 \%$ & 41,32 b & 26,13 \\
$2 \%$ & 37,35 c & 33,25 \\
$3 \%$ & 25,47 d & 54,47 \\
$4 \%$ & 22,15 d e & 60,39 \\
$5 \%$ & 20,11 e & 64,04 \\
\hline KK= 7,54\% & & \\
\hline
\end{tabular}

Angka-angka pada lajur yang sama dan diikuti huruf kecil yang sama adalah berbeda tidak nyata menurut LSD pada taraf $5 \%$.

\section{Berat basah koloni C. gloeosporioides}

Aplikasi ekstrak rebusan daun pepaya dengan konsentrasi $3-5 \%$ telah menurunkan berat basah koloni $C$. gloeosporioides. Efektivitas penekanan perlakuan terhadap berat basah koloni tertinggi ditemukan pada perlakuan $5 \%$ $(45,16 \%)$, akan tetapi secara statitik penurunan berat basah tersebut tidak berbeda nyata dengan perlakuan lainnya (Tabel 4).

\section{Berat kering koloni C. gloeosporioides}

Aplikasi ekstrak rebusan daun pepaya dengan konsentrasi $2-5 \%$ telah menurunkan berat kering koloni $C$. gloeosporioides. Semakin tinggi konsentrasi ekstrak rebusan daun pepaya yang diberikan, semakin rendah berat kering koloninya. Penurunan berat kering koloni tertinggi ditemukan pada C. Gleoesporioides yang diaplikasi dengan konsentrasi $5 \%$, dengan efektivitas penekanan mencapai 45,16\% (Tabel 5). 
Tabel 4. Berat basah jamur C. gloeosporioides setelah diaplikasi dengan ekstrak rebusan daun pepaya pada konsentrasi yang berbeda (umur $14 \mathrm{hsi}$ )

\begin{tabular}{lrlc}
\hline Konsentrasi & Berat Basah (g) & Efektivitas (\%) \\
\hline Kontrol & 3,41 & a & - \\
$1 \%$ & 3,25 & a & 4,69 \\
$2 \%$ & 2,65 & a b & 22,28 \\
$3 \%$ & 2,12 & b & 37,83 \\
$4 \%$ & 2,02 & b & 40,76 \\
$5 \%$ & 1,87 & b & 45,16 \\
\hline KK = 24,5\% & \multicolumn{2}{l}{} \\
\hline Angka-angka pada lajur yang sama dan diikuti huruf kecil yang sama adalah berbeda tidak nyata menurut LSD \\
pada taraf 5\%.
\end{tabular}

Tabel 5. Berat kering koloni C. gleoesporioides setelah diaplikasi dengan ekstrak rebusan daun pepaya pada konsentrasi yang berbeda (umur $14 \mathrm{hsi}$ )

\begin{tabular}{lclc}
\hline Konsentrasi & Berat kering (g) & Efektivitas (\%) \\
\hline Kontrol & 0,48 & a & - \\
$1 \%$ & 0,44 & a b & 8,33 \\
$2 \%$ & 0,41 & b & 14,58 \\
$3 \%$ & 0,33 & c & 31,25 \\
$4 \%$ & 0,30 & c & 37,50 \\
$5 \%$ & 0,22 & d & 54,16 \\
\hline
\end{tabular}

KK $=9,17 \%$

Angka-angka pada lajur yang sama dan diikuti huruf kecil yang sama adalah berbeda tidak nyata menurut LSD pada taraf $5 \%$.

\section{Jumlah konidia C. gloeosporioides}

Aplikasi ekstrak rebusan daun pepaya pada konsentrasi yang berbeda telah menekan jumlah konidia $C$. gloeosporioides. Semakin tinggi konsentrasi ekstrak rebusan daun pepaya yang diberikan, semakin rendah jumlah konidianya. Jumlah konidia terendah dite- mukan pada C. gleoesporioides yang diaplikasi dengan ekstrak rebusan daun pepaya konsentrasi $5 \%$, dengan efektivitas penekanan mencapai $82,5 \%$, namun penekanan jumlah konidia tersebut hanya lebih tinggi dari konsentrasi 1-2\% tapi tidak berbeda nyata dengan perlakuan lainnya (Tabel 6).

Tabel 6. Jumlah konidia C. gloeosporioides/ml suspensi setelah diaplikasi dengan ekstrak rebusan daun pepaya pada konsentrasi yang berbeda (umur $14 \mathrm{hsi}$ ).

\begin{tabular}{llll} 
Konsentrasi & \multicolumn{2}{l}{ Jumlah Konidia/ml suspense } & Efektivitas (\%) \\
\hline Kontrol & $10,0010^{8}$ & a & - \\
$1 \%$ & $7,25.10^{8}$ & b & 27,5 \\
$2 \%$ & $5,00.10^{8}$ & b c & 50,0 \\
$3 \%$ & $3,25.10^{8}$ & c d & 67,5 \\
$4 \%$ & $2,62.10^{8}$ & c d & 73,8 \\
$5 \%$ & $1,75.10^{8}$ & d & 82,5 \\
\hline KK = 32,43\% & &
\end{tabular}




\section{PEMBAHASAN}

Aplikasi ekstrak rebusan daun pepaya telah mempengaruhi warna koloni, penyebaran koloni, dan ketebalan miselia C. gloeosporioides (Tabel 2, Gambar 2), menghambat perluasan koloni (Tabel 3). $\mathrm{Hal}$ ini diduga karena ekstrak rebusan daun pepaya mengandung senya-wa aktif seperti tanin, papain, alkaloid, flavonoid, saponin, dan triterpenoid yang memiliki sifat antijamur maupun antimikroba sehingga mampu memberikan tekanan terhadap pertumbuhan C. gloeosporioides. Suriawiria (2002) menyatakan bahwa daun pepaya mengandung getah berwarna putih dengan kandungan enzim papain yang memiliki aktivitas proteolitik dan pemecah protein. Selain itu, Tsuchiya et al. (1996) menyatakan bahwa flavonoid dapat merusak membran sel jamur. Chuang et al. (2007) juga melaporkan bahwa terpenoid dapat menyebabkan kematian sel atau lisis, sedangkan tannin dapat menghambat enzim dan protein ekstraseluler yang memberikan efek langsung terhadap membran sel.

Perlakuan ekstrak daun pepaya juga mempengaruhi ketebalan miselia jamur karena terhambatnya luas koloni jamur. Fenomena ini diduga karena ekstrak daun pepaya menyebabkan jamur tidak mampu menyebar atau berkembang sehingga membentuk pertahanan dengan memanfaatkan nutrisi yang ada pada PDA. Dengan demikian, semakin lama jamur akan semakin rapat akan mendesak dan mengumpul di bagian tengah. Hal ini sesuai dengan pendapat Ariani (2016) yang menyatakan bahwa senyawa antijamur yang dihasilkan oleh ekstrak daun pepaya dengan konsentrasi berbeda akan memiliki kemampuan menghambat pertumbuhan $C$. capsici.

Aplikasi ekstrak rebusan daun pepaya mampu menurunkan berat basah dan berat kering koloni $C$. gloeosporioides (Tabel 4, Tabel 5). Hal ini sesuai dengan penelitian Arneti et al. (2017), bahwa pada perlakuan yang menyebabkan perluasan koloni terkecil menunjukkan berat basah dan berat kering terendah, dan perluasan koloni tertinggi menunjukkan berat basah dan berat kering tertinggi pula seperti yang ditemukan pada perlakuan ekstrak daun ketepeng cina (Cassia alata) yang diujikan pada C. gloeosporioides.

Selain mempengaruhi luas koloni, berat basah dan kering jamur, aplikasi ekstrak rebusan daun juga mampu menekan pembentukan konidia (Tabel 6). Terhambatnya pembentukan konidia akan menghambat perkembangan jamur lebih lanjut. Menurut Ella et al. (2013) apabila pembentukan konidia dapat dihambat, maka pertumbuhan jamur juga dapat ditekan secara keseluruhan.

Semakin tinggi konsentrasi ekstrak rebusan daun pepaya yang diberikan, menyebabkan semakin tinggi pula tekanannya terhadap C. gloeosporioides. Koul et al. (2008) menyatakan, pada konsentrasi tinggi maka semakin tinggi pula senyawa-senyawa metabolitnya yang menyebabkan pertumbuhan koloni jamur semakin terhambat. Salome (1999) juga menyatakan bahwa semakin tinggi kandungan bahan aktif tumbuhan maka pengaruhnya terhadap pertumbuhan jamur semakin besar. Menurut Arianti et al. (2012), tinggi rendahnya konsentrasi ekstrak dapat mempengaruhi kinerja ekstrak. Aplikasi pada konsentrasi tinggi dapat bersifat toksik yaitu mampu meracuni jamur dan menghentikan pertumbuhannya, tetapi jika aplikasi dilakukan pada konsentrasi rendah akan bersifat fungistatis yang hanya mampu menghambat pertumbuhan jamur. Aplikasi pada konsentrasi 5\% memiliki efektivitas penekanan tertinggi, akan tetapi menunjukkan signifikansi yang berbeda pada semua indikator pengamatan. 
Meskipun zat aktif yang terkandung dalam ekstrak rebusan daun pepaya dalam menghambat $C$. gloeosporioides dilapangan belum diketahui secara pasti. Akan tetapi, hasil penelitian ini menunjukkan bahwa ekstrak rebusan daun pepaya mampu menghambat dan menekan pertumbuhan jamur $C$. gloeosporioides secara invitro, sehingga diharapkan dapat menjadi dasar pengembangan salah satu alternatif pengendalian penyakit tanaman yang efektif dan ramah lingkungan.

\section{KESIMPULAN}

Aplikasi ekstrak rebusan daun pepaya dengan konsentrasi yang berbeda dapat menekan pertumbuhan Colletotrichum gloeosporioides penyebab penyakit antraknosa pada buah cabai secara in vitro. Semakin tinggi konsentrasi ekstrak rebusan daun papaya yang diberikan, semakin tinggi efektivitasnya dalam menekan pertumbuhan C. Gloeosporioides. Aplikasi pada konsentrasi 5\% paling efektif menghambat efektif dalam menghambat menghambat pembentukan konidia $(82,5 \%)$, diikuti kemampuannya dalam menghambat perluasan koloni $(64,04 \%)$, serta menurunkan berat basah $(45,16 \%)$ dan berat kering $(54,16 \%)$.

\section{DAFTAR PUSTAKA}

Ariani K. 2016. Uji efektivitas ekstrak daun pepaya (Carica papaya L.) sebagai fungisida alami terhadap jamur Colletotrichum capsici (Syd. Butler \& Bisby) penyebab penyakit antraknosa pada tanaman cabai merah (Capsicum annuum L.). [Skripsi]. Universitas Lampung. Bandar Lampung.

Arianti EL, R Jahuddin, dan M Yunus. 2012. Potensi ekstrak daun sirih (Piper betle Linn.) sebagai biofungisida penyakit busuk buah stroberi (Colletotrichum fragariae) secara in vitro. Jurnal Agroteknos 2(3): 171174.
Arneti, E Sulyanti dan Murniati. 2017. Pengujian ekstrak sederhana bagian tumbuhan Cassia alata Linneus terhadap Colletotrichum gloeosporioides secara in-vitro. Jurnal Proteksi Tanaman 1(2): 42-51.

Asmaliyah W, EE Utami, S Mulyadi, Yudhistira dan FW Sari. 2010. Pengenalan tumbuhan penghasil pestisida nabati dan pemanfaatannya secara tradisional. Badan Penelitian dan Pengembangan Kehutanan. Palembang.

Barnet HL dan BB Hunter. 1972. Ilustrated genera of imperfect fungi. $4^{\text {th }}$ edition. The American Phytopathological Society. USA .

BPS [Badan Pusat Statistik]. 2018. Luas Panen, produktivitas, produksi tanaman cabai nasional. Badan Pusat Statistik. Jakarta.

Chuang $\mathrm{P}, \mathrm{C}$ Lee, J Chou, M Murugan, B Shieh dan H Chen. 2007. Anti-fungal activity of crude extracts and essential oil of Moringa oleifera Lam. Bioresource Technology 98: 232-236.

Duriat AS, G Neni dan WW Astri. 2007. Penyakit penting pada tanaman cabai dan pengendaliannya. Laporan Penelitian. Balai Penelitian Tanaman Sayuran. Bandung.

Ella MU, K Sumiartha, NW Suniti, IP Sudiarta dan NS Antara. 2013. Uji efektivitas konsentrasi minyak atsiri sereh dapur (Cymbopogon citrates (DC.) Stapf) terhadap pertumbuhan jamur Aspergillus sp. secara in-vitro. Jurnal Agroekoteknologi Tropika 2(1): 39-48.

Haryani A, R Granduosa, ID Buwono, dan A Santika. 2012. Uji efektifitas daun pepaya (Carica papaya) untuk pengobatan infeksi bakteri Aeromonas Hydrophila pada ikan Mas Koki (Carassius auratus). Jurnal 
Perikanan dan Kelautan 3(3): 213220.

Jati NK. 2016. Isolasi, identifikasi, dan uji aktivitas antibakteri senyawa alkaloid dari daun pepaya (Carica papaya L.). [Skripsi]. Universitas Negeri Semarang. Semarang.

Koul O, S Walia dan GS Dhaliwal. 2008. Essential oils as green pesticides: Potential and constraints. Biopesticides International 4: 63-84.

Nurahmi E, T Mahmud dan S Rossiana. 2011. Efektifitas pupuk organik terhadap pertumbuhan dan hasil cabai merah. Jurnal Floratek 6: 158164.

Park SK. 2005. Differential interaction between pepper genotypes and Colletotrichum Isolates causing antracnose. [Thesis]. Seoul National University. Seoul.

Purnomo, D. 2008. Aplikasi getah dua genotipe pepaya betina sebagai biofungisida untuk mengendaliakn penyakit antraknosa (Colletotrichum capsici (Syd.) Bult \& bisby) pada cabai merah besar (Capsicum annuum L.). [Skripsi]. Departemen Proteksi Tanaman. Fakultas Pertanian IPB. Bogor.

Salome R. 1999. Isolasi karotenoid dari daun surian (Toona sureni (BI) Merr.). [Tesis]. Program Pascasarjana Universitas Andalas. Padang.

Siregar EBT dan HK Emmy. 2005. Rekayasa genetika tanaman cabai (Capsicum annuum L.) tahan virus mosaik ketimun (CMV). Jurnal Komunikasi Penelitian 17(2): 30-36.

Suriawiria. 2002. 10 tanaman berkhasiat sebagai obat: Kanker, tumor, diabetes, tekanan darah tinggi, jantung, ginjal, liver, stroke, dan lain-lain. Papas Sinar Sinanti. Jakarta.

Tsuchiya HM, T Sato, S Miyazaki, S Fujiwara, M Tanigaki, T Ohyama, I Tanaka, Takase dan M Linuma. 1996. Comparative study on the antibacterial activity of phytochemical flavanones against methicillinresistant Staphylococcus aureus. Ethnopharmacol Journal 50: 27-34. 